\title{
AS INTERFACES DO PROCESSO DE CONSTRUÇÃO DE ESTRATÉGIAS IDENTITÁRIAS DE JOVENS BRASILEIROS EM PORTUGAL
}

GRACIOLI, Maria Madalena ${ }^{1}$

Recebido em: 2020.09.04 Aprovado em: 2020.11.27ＩSSUE DOI: $10.3738 / 1982.2278 .3837$

\begin{abstract}
RESUMO: A inserção de jovens imigrantes na sociedade acolhedora perpassa diversos espaços de socialização: escolas, universidades, trabalho, espaços de cultura e lazer; são nesses ambientes que surgem oportunidades de convívio com jovens e com a cultura do país receptor. No entanto, nem sempre essa experiência se faz positiva; muitas vezes é permeada por estereótipos, preconceitos e discriminação, levando os jovens de forma consciente ou inconsciente, utilizar estratégias identitárias. Baseando-se nos estudos de Camilleri, Kastersztein e Taboada-Leonetti (2013), que discutem o conceito de estratégias identitárias, e, de Hall (2000, 2006), Dubar (2006) e Bauman (2005) que tratam os processos de construção da identidade e, na investigação realizada a partir de um trabalho de campo elaborado por meio de entrevistas com jovens brasileiros com idade entre 16 e 24 anos, imigrantes em Portugal, identificamos e analisamos três tipos de estratégias identitárias utilizadas por esses jovens, a estratégia identitária defensiva, a estratégia identitária de assimilação, e a estratégia identitária por distinção.
\end{abstract}

Palavras-chave: Jovens. Migrantes. Fronteiras identitárias. Identidade.

\section{INTERFACES OF BUILDING PROCESS OF IDENTITY STRATEGIES FOR YOUNG PEOPLE IN MIGRATORY CONTEXT}

SUMMARY: The insertion of young immigrants in welcoming society permeates several spaces of socialization: schools, universities, work, spaces for culture and leisure. It is in these environments that opportunities for socializing with young people and with culture of the receiving country arise. However, this experience is not always positive and is often permeated by stereotypes, prejudices and discrimination, leading young people, consciously or unconsciously, to use identity strategies. Based on studies by Camilleri, Kastersztein and Taboada-Leonetti (2013), which discuss the concept of identity strategies and, bay Hall (2000, 2006), Dubar (2006) and Bauman (2005) who deal with the processes of identity construction and on the research carried out through fieldwork elaborated through interviews with young Brazilians aged between 16 and 24 years old, immigrants in Portugal, we identified and analyzed three types of identity strategies used by these young people: defensive identity strategy, assimilation identity strategy and distinction identity strategy.

Keywords: Youth; Migrants; Identity borders; Identity.

\section{INTRODUÇÃO}

Muitos estudos relevantes já foram realizados sobre a imigração brasileira em Portugal, poucos deles voltados especificamente para os jovens enquanto categoria social, que na maioria das vezes são considerados como adultos jovens, ou frequentemente denominados como "trabalhador jovem", "filho de trabalhador imigrante", "estudantes imigrantes", "aluno

\footnotetext{
${ }^{1}$ Doutora em Sociologia com Pós-doutorado pelo Centro de Estudos Sociais - CES, da Universidade de Coimbra, é professora da Faculdade de Filosofia Ciências e Letras de Ituverava FFCL/FE e docente do Programa de Pósgraduação em Análise e Planejamento de Políticas Públicas da Unesp - Franca.
} 
imigrante", entre outras denominações utilizadas em estudos migratórios e/ou documentos oficiais sobre imigração, no entanto, conhecer e analisar a questão juvenil em contextos migratórios é de suma importância, tanto no terreno científico das migrações internacionais, quanto para dar respostas adequadas às necessidades que esse grupo demanda na nova sociedade, seja na sua inserção no mercado de trabalho, na escola, formação profissional e em atividades culturais e de lazer.

Grande parte dos jovens que migra não o faz sozinho, é parte de uma família, cuja decisão de migrar coube aos pais, como é o caso dos jovens analisados nesse artigo, que acompanham os pais no processo migratório em Portugal.

No país de destino, muitos jovens migrantes enfrentam dificuldades, iguais, senão maiores que os adultos, precisam conviver com a discriminação, o racismo, preconceitos e estereótipos, dificuldades de acesso ao estudo e ao emprego decente, obstáculos que retardam a sua integração na nova sociedade, e assim, violam sua condição de sujeitos de direitos e fere a sua identidade. Tanto quanto a decisão de migrar é individual ou mesmo nascida em seio familiar, o migrante não se desapega das suas origens e procura preservar alguns traços e manter laços com cultura na qual nasceu, seja pela conservação da língua, religião, alimentação, cultura e modos de agir e pensar, que é comparada com a cultura, valores, modos de agir e pensar da nova sociedade, colocando sua identidade num constante processo de confrontação e transformação, pois passa a ser permeada por mudanças nas relações com a nova sociedade, com o meio que o cerca, mas também, com a sociedade e cultura do país de origem.

O jovem migrante vive uma dupla fase de transição, a primeira característica dessa fase da vida - transição para a vida adulta, a segunda, corresponde a uma transição geográfica e cultural entre seu país de origem, no caso em estudo, o Brasil, colônia portuguesa por mais de 400 anos, clima tropical, extensão territorial continental, rico em biodiversidade, povo constituído pelo cruzamento de diversas raças/etnias, prevalecem enormes desigualdades sociais; e Portugal, país do hemisfério norte, de clima temperado, integrante na União Europeia, com cultura, valores e condições socioeconômicas díspares, com a mesma língua, mas com variações e sotaque diferentes. Portanto, não se trata apenas de uma transição espacial, mas principalmente, social e cultural. Associado a isso, encontram-se os desafios da inserção na nova sociedade e a necessidade de conviver com os jovens do novo lugar de vida que, consequentemente, exigem constantes questionamentos sobre si mesmos, forçando-os a adotar uma ou mais estratégias identitárias que têm a função de preservar a sua identidade e/ou como meio de interagir com os membros da nova sociedade. 
Muitos estudos, entre eles Machado (2003), Malheiros (2007), Padilha (2006, 2007), Peixoto; Figueiredo (2006), revelam a existência de fortes estereótipos atribuídos à comunidade brasileira que vive em Portugal, além do preconceito e da discriminação que vivenciam diariamente. A análise do corpus das entrevistas realizadas com jovens brasileiros revela que para sobreviverem e conviverem na nova sociedade, adotam diferentes estratégias identitárias, semelhantes às que Camilleri (2013) encontrou nos seus estudos sobre os imigrantes em França. Esse artigo corresponde a um recorte de uma pesquisa realizada com jovens brasileiros em Portugal, e tem por objetivo analisar as estratégias identitárias utilizadas por esses jovens no processo de integração na nova sociedade.

A primeira parte desse artigo destina-se a discutir o conceito de identidade tomando como referência a Psicologia social (Lipiansky, Taboada-Leonetti e Vasques) e a Sociologia (Hall, Bauman, Dubar) e o conceito de estratégia identitária, buscando referência em trabalhos desenvolvidos por Lipiansky, Taboada-Leonetti e Vasques, Camilleri e Kastersztein. Na segunda parte, num recorte das entrevistas realizadas com jovens brasileiros que na época das entrevistas viviam na cidade do Porto, região da grande Lisboa e Costa da Caparica, identifica e discute três diferentes estratégias identitárias empregadas por eles para enfrentar a desvalorização da sua identidade cultural.

\section{Identidade e Estratégias identitárias}

A noção de identidade tem as suas raízes em diferentes correntes do pensamento e em diferentes disciplinas, como na Antropologia, na Psicologia social e na Sociologia. A Sociologia e a Psicologia são as áreas que mais têm avançado nos estudos sobre a identidade; Hall (2000) afirma que o conceito de identificação é pouco desenvolvido no campo das Ciência Sociais, que para melhor compreensão procura se apoiar em conceitos da Psicanálise; também Dubar (2005, p. 134) diz ser necessário recorrer à "psicanálise e a suas aquisições mais sólidas" para compreender a identidade; Taboada-Leonetti (2013) explica que podemos dizer grosseiramente que a Psicologia se interessa pela identidade individual e a Sociologia pela identidade coletiva, mas que na realidade estas duas entidades são indissociáveis, porque não há identidade coletiva que não seja produzida e gerada no seio das identidades individuais.

Hall (2000, p. 106) entende a identidade como "uma construção, como um processo nunca completado - como algo sempre 'em processo'. De forma semelhante Dubar (2005) entende a identidade como decorrência da socialização, processo esse sempre em construção e (re)construção, “a identidade nunca é dada, ela sempre é construída e deverá ser (re)construída em uma incerteza maior ou menor e mais ou menos duradoura" (2005, p. 135), e completa que “identidade nada mais é que o resultado a um só tempo estável e provisório, individual e coletivo, 
subjetivo e objetivo, biográfico e estrutural, dos diversos processos de socialização que, conjuntamente, constroem os indivíduos e definem as instituições",2 (DUBAR, 2005, p. 136). Para Bauman (2005), a identidade surge no contexto das "comunidades", a qual na sociedade líquido moderna, as certezas dão lugar à fluidez, e afirma que a identidade assim como o pertencimento "não tem a solidez de uma rocha, não são garantidos para toda a vida, são bastante negociáveis e revogáveis" (p. 17).

Para Stuart Hall (2006, p. 9), as transformações ocorridas no final do século XX geraram a fragmentação do indivíduo moderno, "abalando a ideia que temos de nós próprios como sujeitos integrados". Argumenta que esta perda de "sentido de si", consequência dessa fragmentação que altera as identidades pessoais, gera o "deslocamento e descentração" do sujeito, gerando uma "crise de identidade". Assim, para ele, a identidade já não é mais estável uma vez que "o processo de identificação, através do qual nos projetamos em nossas identidades culturais, tornou-se mais provisório, variável e problemático" (HALL, 2006, p. 12); para ele, a identidade, antes única e estável, torna-se fragmentada, composta "não de uma, mas de várias identidades, algumas vezes contraditórias ou não-resolvidas", e cita o crítico cultural Kobena Mercer, que observa que "a identidade se torna uma questão quando está em crise, quando algo que se supõe como fixo, coerente e estável é deslocado pela experiência da dúvida e da incerteza (MERCER, 1990, p. 43, apud HALL, 2006, p. 9). O autor entende que:

As identidades não são nunca unificadas; que elas são, na modernidade tardia, cada vez mais fragmentadas e fraturadas; que elas não são nunca singulares, mas multiplamente construídas ao longo do discurso, práticas e posições que podem se cruzar ou ser antagônicas. As identidades são sujeitas a uma historicização radical, estando constantemente em processo de mudança e transformação (HALL, 2000, p. 108).

Claude Dubar (2005, p. 139) afirma ser a identidade um produto das sucessivas socializações, nas quais a identidade social é marcada pela dualidade, uma vez que resulta da articulação de dois processos: o "processo biográfico", que gera a "identidade para si”, que deriva de "atos de pertencimento" e exprimem o "tipo de homem ou de mulher se quer ser, que você diz que você é", ou seja, a "incorporação da identidade pelos próprios indivíduos" (p. 139), e compara esse processo com a expressão utilizada por Goffman como "identidades sociais reais"; e, o "processo relacional", que forja a "identidade para o outro", resultante de "atos de atribuição" que definem o tipo de homem ou mulher que se é, dizem que você é, produzindo uma forma de rotulagem que "Goffman denomina de identidades sociais 'virtuais'[...]".

Portanto, para Dubar existem modos de identificação que são variáveis ao longo da história tanto coletiva, quanto individual e dependem do contexto histórico. Desse modo, a

${ }^{2}$ Grifos do autor

Nucleus, v.18, n.1, abr. 2021 
identidade para si e a identidade para o outro compõem uma dualidade que são "inseparáveis e ligadas de maneira problemática" (DUBAR, 2005, p.135). Defende ainda, que sempre podemos aceitar ou recusar as identidades que nos são atribuídas e que podemos nos identificar com uma forma que não é a que nos é atribuída, e completa "é a relação entre estes dois processos de identificação que está na base da noção de formas identitárias” (DUBAR, 2006, p. 9).

Zygmunt Bauman (2005, p. 17), também numa perspectiva sociológica, explica a existência de dois tipos de comunidade: as de vida e de destino, cujos membros "vivem juntos numa ligação absoluta" e as comunidades de ideias, formadas por uma variedade de princípios. Assim, a identidade assenta-se nas comunidades da segunda categoria por haver mais ideias num mundo de diversidade e de policulturas, e na crença da constante necessidade de contínuas escolhas. Para ele:

A "identidade" só nos é revelada como algo a ser inventado, e não descoberto; como alvo de um esforço, "um objetivo"; como uma coisa que ainda se precisa construir a partir do zero ou escolher entre alternativas e então lutar por ela e protegê-la lutando ainda mais - mesmo que, para que essa luta seja vitoriosa, a verdade sobre a condição precária e eternamente inconclusa da identidade deva ser, e tenda a ser, suprimida e laboriosamente oculta. (BAUMAN, 2005, p. 21-22)

Esclarece que há atualmente uma infinidade de identidades à escolha, e outras ainda a serem inventadas, e que não mais se podem ocultar a fragilidade e condição provisória da identidade.

Lipiansky, Taboada-Leonetti e Vasques (2013), no campo da Psicologia social, consideram que mesmo com diferentes quadros de análise sobre a questão da identidade, é possível verificar atualmente um certo consenso no sentido de se abandonar a ideia da existência de uma única identidade, como inicialmente foi formulada pela corrente psicanalítica, de supor que cada indivíduo pode dispor sucessivamente, ou mesmo simultaneamente, de numerosas identidades, dependendo do contexto histórico, social e cultural em que num determinado momento esteja inserido.

Por sua vez, as estratégias identitárias correspondem a uma reação tácita acerca daquilo que constitui o problema da situação e que leva o indivíduo a optar por agir numa determinada direção e/ou assumir posições. No entanto, vale destacar que assim como a identidade, as estratégias identitárias não devem ser consideradas como definitivas ou únicas, pois dependendo do contexto a pessoa pode adotar diferentes estratégias. Toma-se aqui a seguinte definição para estratégia identitária:

Procedimentos elaborados (em níveis de elaboração conscientes ou inconscientes) por um ator social (individual ou coletivo) a fim de atingir um ou mais objetivos (conscientes ou inconscientes); estes procedimentos são elaborados em função da situação de interação e dependem de diversas determinações (sócio históricas, culturais, psicológicas) dessa situação. (LIPIANSKY; TABOADA-LEONETTI; VASQUEZ, 2013, p.24) 
De forma análoga, Kastersztein (2013) entende as estratégias identitárias como comportamentos individuais ou coletivos, conscientes ou inconscientes, adaptados ou inadaptados, configurados para alcançar vitórias contra um adversário que pode ser ele mesmo, outros indivíduos em interação concreta (família, amigos, colegas...), ou o sistema social. Para ele, uma das finalidades essenciais das estratégias identitárias para o indivíduo é o reconhecimento da sua existência no sistema social; desse modo, por um lado, é preciso que o sistema o reconheça num lugar específico, e, por outro, que o próprio indivíduo perceba subjetivamente esse reconhecimento, tendendo dessa forma, a delimitar objetivos que possam admitir essa pertença ou demonstrar interesse de interação.

Taboada-Leonetti (2013) inicia a discussão sobre estratégias identitárias, apresentando a noção de estratégia por ela entendida como:

\footnotetext{
"um conjunto de dispositivos utilizados pelos jogadores para alcançar um objetivo" (Larousse), ou, por referência a teoria dos jogos matemáticos, como "um conjunto de decisões tomadas em função de hipóteses feitas sobre os comportamentos dos parceiros do jogo" (definição que tem a vantagem de introduzir a ideia de interação), sugerindo, portanto, que possa ser aplicada aos fenômenos sociais ou psicológicos pela existência duma certa liberdade de ação dos atores sobre possíveis determinismos sociais ou existenciais. (TABOADALEONETT, 2013, p. 49)
}

Para a autora, as estratégias identitárias podem ser entendidas como o resultado do desenvolvimento individual e coletivo, são ajustados de acordo com as mudanças de situações e propósitos expressos pelos atores e são necessários três elementos: os atores (individuais ou coletivos), a situação e desafios em que os atores estão envolvidos e os fins perseguidos pelos atores.

Camilleri (2013), ao estudar os imigrantes em França, observa que o imigrante vive em contato com a cultura de origem e com a cultura da sociedade de acolhimento, gerando conflito e a fragmentação cultural, consequentemente sofre uma pressão psicológica que impacta sua identidade. Esse impacto vai refletir-se em alterações, pois o imigrante experimenta danos no sentido de unidade, o equilíbrio é prejudicado, uma vez que os valores tradicionais com que ele se identifica, ou seja, aqueles que definem a sua identidade original, se confrontam com o seu novo ambiente social.

Esse autor distingue duas funções das estratégias identitárias: as estratégias que valorizam a função ontológica da identidade, ou seja, um investimento no eu e na origem, e as que valorizam a função pragmática da identidade, isto é, investimento na adaptação ao meio e às situações. Ele identifica uma série de estratégias identitárias relativas à forte dependência das identidades atribuídas pelos grupos maioritários, divididas em dois grupos, as identidades dependentes e as identidades reacionárias. 
No grupo das estratégias identitárias dependentes estão (CAMILLERI, 2013):

Identidades negativas: o indivíduo interioriza o valor negativo atribuído a sua identidade e adota uma atitude submissa perante o grupo maioritário. Frequentemente, são adotadas por aqueles que ocupam posição de desvantagem na relação com o outro e introjeta o valor depreciativo da sua identidade, supervaloriza a função ontológica da identidade, procurando conservar a identidade de origem.

Identidades negativas deslocadas ou por assimilação: essa estratégia permite ao indivíduo não interiorizar a estigmatização negativa. Por meio dessa estratégia procura integrar-se ao grupo de acolhida, e recusa qualquer contato com suas origens. Valorização da função pragmática, mas conserva um mínimo da função ontológica.

Identidade por distinção: o indivíduo toma consciência da sua singularidade, mas não interioriza as identidades negativas atribuídas, estabelece certa distância das identidades atribuídas, aceitando suas diferenças, permitindo uma situação de equilíbrio identitário que o indivíduo procura estabelecer, nesse sentido, elabora um discurso moderado e relativamente neutro sobre a sociedade de origem e a sociedade receptora. Nessa estratégia há uma supervalorização da função pragmática, investindo quase que exclusivamente na sociedade de acolhimento e na adaptação.

As estratégias reacionárias foram divididas por Camilleri (2013) em três grupos:

Identidade de defesa: identidade como recusa, escudo para se proteger, o imigrante constrói um discurso negativo do contexto social do país receptor, percebendo que é vítima de discriminação e exclusão; no entanto, ele não se assume como vítima, como no caso daqueles que adotam a identidade negativa, e sim como sujeito ativo de sua trajetória enquanto migrante. Trata-se de uma "bricolagem" da identidade, ou seja, construção da identidade por si e não em si.

Identidade polêmica: aqui o sujeito não somente se distingue ou se protege dos outros percebidos como ameaçadores, mas se firma mais ou menos agressivamente, se posicionando contra eles. Predomina a lógica racional com a articulação orgânica dos contrários.

Identidade de princípio: consiste paradoxalmente numa forte reivindicação de pertença ao grupo de origem quando, na prática, rejeitam os valores e formas de ser do grupo. É uma estratégia problemática que não evita os conflitos.

Com base nos pressupostos que apresentamos e no trabalho de campo desenvolvido, partiremos para os três tipos de estratégias identitárias identificadas nas entrevistas realizadas jovens brasileiros imigrantes em Portugal. 


\section{Estratégias identitárias de jovens brasileiros imigrantes em Portugal}

A identidade pessoal ou coletiva vale-se de fronteiras identitárias, para fazer uma distinção entre "eu" e o "outro" ou "nós" e os "outros". Assim, os processos de construção da identidade se apropriam de elementos culturais, que fornecem informações necessárias para a construção de fronteiras simbólicas daquilo que é "meu" ou "nosso" e aquilo que é do "outro" ou são dos "outros", já que não partilham do mesmo conjunto de marcadores identitários. Acrescenta-se ainda que a construção da identidade não se faz apenas de referências culturais, mas também de características sociais, como idade, gênero, classe social. $\mathrm{Na}$ construção da identidade juvenil os aspectos sociais são fortemente determinantes.

$\mathrm{Na}$ sociedade portuguesa, os jovens brasileiros frequentam diferentes espaços, escola de educação básica, cursos profissionalizantes, universidades, trabalho, espaços de cultura e lazer. São nesses espaços que têm a oportunidade de conviver com jovens portugueses e entrar em contato com a cultura portuguesa, mas nem sempre essa experiência é positiva, muitas vezes é permeada por preconceito, discriminação e por estereótipos, conforme apontam estudos citados na introdução deste texto.

No corpus das entrevistas, foi possível identificar três diferentes estratégias identitárias apontadas nos estudos de Camilleri (2013) e utilizadas pelos jovens brasileiros. A primeira corresponde às estratégias identitárias defensivas, utilizada por aqueles que tentam preservar a identidade a todo custo e, para isso, apegam-se aos valores da cultura brasileira e valem-se das boas memórias que guardam do Brasil; a segunda, corresponde àqueles que utilizam estratégias identitárias de assimilação, que procuram se assemelhar ao grupo de referência, tentando negociar e ao mesmo tempo reinventar a identidade para serem aceitos no grupo e, para isso, adotam uma imagem negativa do brasileiro, e, por último, os jovens que recorrem às estratégias identitárias por distinção, procurando (re)construi-la alinhavando pedaços das duas culturas, tentam ir aos poucos incorporando alguns elementos da nova cultura, sem precisar abrir mão da sua identidade de origem e, desse modo, vão encontrando formas de conviver com os jovens portugueses e de viver plenamente esse especial período da vida.

Os jovens, ao circularem por diferentes espaços sociais, principalmente aqueles percebidos como ameaçadores, são desafiados a recorrer às diferentes estratégias identitárias que permitem atuar sobre construções simbólicas de suas identidades para mantê-las ou (re)inventálas. Sendo assim, podem adotar uma ou diferentes estratégias identitárias em função do contexto.

Caetano, um rapaz de 18 anos, branco, nascido numa família humilde, num bairro de periferia, na cidade de Porto Velho, Rondônia, na época da entrevista vivia há três anos na Costa da Caparica com a mãe e o irmão. Afirma, em seu depoimento, que a maioria dos amigos é 
composta por brasileiros, fala da discriminação e do preconceito que vivencia cotidianamente e demonstra apegar-se às memórias e a idealização do país de origem valendo-se de estratégia identitária identificada por Camilleri (2013) como de defesa:

\begin{abstract}
Meu corte de cabelo ainda é o mesmo que usava no Brasil, o estilo das minhas roupas também, no carro da minha mãe é só música brasileira, não vale a pena escutar fado né? Eu não mudei nada, e não quero aprender o sotaque português, quando alguém fala que estou falando como os portugueses, tento mudar, porque sou brasileiro e não português, e é assim que quero viver.
\end{abstract}

Aqui a gente precisa ter muito cuidado porque eles pensam que todos os brasileiros são ladrões, traficantes e arrumadores de confusão, então eu prefiro andar com meus amigos que são brasileiros, com meu irmão, meus primos e minha namorada que também é brasileira.

Sinto falta dos meus colegas de lá, crescemos todos juntos, era todo mundo indo para escola junto, voltando junto, brigava hoje, amanhã já estava junto de novo, ia jogar bola brigava, uma hora depois já estava junto de novo, quando saía para o rio, ou para o sítio, essas coisas assim, era carne para assar, muita coisa para comer, isso me faz falta, porque aqui isso não existe.

Acho que aqui é para eu conquistar as coisas e depois que eu tiver minhas coisas conquistadas quero colocar lá no Brasil, naquilo que eu quero, vou embora para lá de vez, fico lá, mas, se eu ver que aqui não está dando aquilo que quero, vou para lá para tentar explorar aquilo que tem lá, mas quero mesmo é voltar porque a gente gosta mesmo é de morar no teu lugar, saí de lá foi por causa da precisão (necessidade), mas tenho vontade de voltar.

Nota-se que o jovem adota uma identidade de defesa ao entender que sua identidade cultural é estigmatizada no contexto social do país acolhedor, percebe a discriminação e o preconceito. Assim, o ambiente que não lhe é favorável para expressão da sua identidade e vivência daquilo que é natural na juventude, deixando esse jovem desmotivado, com baixa ou pouca esperança no futuro, um tanto ou quanto sem direção e perspectiva.

O preconceito, a discriminação, os estereótipos e as poucas oportunidades são bastante angustiantes para esse jovem que vive numa fase delicada da vida, são problemas vivenciados a partir de uma posição migrantes na nova sociedade, visto como "o outro", "o estrangeiro", “o brasileiro" surgindo daí um apego às memórias e imagens do país em que nasceu. Há uma tendência para sobrevalorizar as experiências vividas anteriormente; deseja manter laços com o passado, procurando (re)construí-los a partir de memórias e de representações simbólicas, colocando o projeto migratório em constante confronto, as frustrações, as perdas e os ganhos de um projeto que, se não fosse familiar, seria para ele provisório ou inexistente.

Como reação à violação da sua identidade, fecha-se às mudanças e a todas as ideias, valores e cultura do novo lugar de vida, tenta preservar a todo custo uma identidade que não quer colocar em negociação. Evidentemente que isso causa angústia e sofrimento. As violências simbólicas sofridas e a rejeição da sua identidade cultural são fatores que alimentam a saudade da 
terra natal e, ao mesmo tempo, dificultam a identificação com o novo lugar de vida, e consigo mesmo, pois já não é o mesmo.

Estão evidentes as dificuldades que o jovem enfrenta para (re)elaborar sua identidade, já que é no passado que procura suas referências. Há um forte sentimento de identificação com a cultura de origem, com o modo em que estabelecia as relações de amizade, com isso, encontra dificuldade em viver plenamente o presente e de planejar o futuro. Apegar-se às memórias é uma forma de reivindicar a identidade de origem, mesmo que esta seja o principal fator de constantes constrangimentos, surgindo daí o desejo de retorno ao seu país, pois acredita que lá será acolhido pelos familiares que ficaram e pelos amigos. Nota-se, que a expectativa se assenta em manter esperança em algo que possa ser melhor que a angústia do presente.

Sentindo-se desvalorizado na nova sociedade, o jovem imigrante introjeta essa desvalorização. A exclusão que sofre em função de possuir uma identidade cultural que é motivo de discriminação e preconceito, associada à resistência de membros da sociedade em aceitar o imigrante com suas diferenças culturais, serve para reforçar o sentimento de humilhação expressa em seu sofrimento.

Esse jovem e tantos outros que vivem nas mesmas condições procuram (re)orientar-se no interior dessa nova sociedade, para ele ou para eles, complexa, e por vezes hostis. Idealizam a própria origem e as vivências do passado, que funcionam como um mecanismo de autodefesa e representam pontes de continuidade. Há, desse modo, a criação de uma fronteira identitária defensiva, apegada às memórias e recordações que têm a função de preencher o vazio de pertença, que gera sofrimento, pois para viver na nova sociedade, cotidianamente precisa abandonar um pouquinho de si mesmo, um pouquinho do seu passado.

Existe uma tendência de isolamento, da busca de participação apenas no grupo que reconhece sua identidade, nesse caso, o de jovens brasileiros, e tende a estabelecer um distanciamento da cultura e das práticas dos jovens locais. No depoimento desse e de outros jovens revela-se que as festas na casa de amigos brasileiros ou em bares (café) de brasileiros são momentos muito desejados, pois interrompem o isolamento e permitem viver e expressar a sua verdadeira identidade. No entanto, se por um lado esses momentos representam a possibilidade de convivência, sociabilidade, contato com elementos culturais do Brasil, tais como a música, o churrasco, a caipirinha, o jeito brasileiro de "jogar conversa fora", contar piadas, falar da própria vida e da vida dos outros, por outro, corresponde a uma fronteira identitária entre o "nós", os brasileiros e "eles", os portugueses.

A socialização desses jovens ocorre num restrito quadro de alternativas, a convivência com jovens portugueses é muitas vezes uma relação tensa e contraditória, na qual as realizações 
de práticas juvenis terminam subordinada às exigências de convivência e a aceitação da negociação da identidade, passando a ser uma alternativa inevitável para ser aceito no grupo, como no caso a seguir.

De forma oposta, seu irmão Claudio, 17 anos, também nascido na cidade de Porto Velho Rondônia, sente necessidade de aceitação no grupo, de ser reconhecido, de ter amigos, de maior interação com jovens do país acolhedor, para isso, negocia a identidade, adotando uma estratégia identitária reconhecida por Camilleri (2013) como de assimilação e cria como mecanismo de defesa uma imagem negativa dos brasileiros.

Eu ficava isolado, não tinha amigos, então para ser amigo deles tive que aprender a falar com o sotaque português, ouvia na televisão, ouvia os professores e quando estava na rua ia falando sozinho para treinar. Também mudei o modo de vestir, porque a gente convive quase sempre, então quando vejo eles com uma roupa legal, copio, assim uso o mesmo tipo de roupa, as mesmas marcas.

Meus amigos são portugueses, porque aqui conviver com brasileiros é muito pesado, porque a maioria que está cá não presta, fazem coisas que é crime, então meu relacionamento é mais com portugueses, com eles posso ir a Lisboa, para discotecas, ou então, para Almada em cinemas ou Centros de compra.

Os portugueses pensam que todos os brasileiros têm que ser jogador de futebol, eu não queria isso, então meus amigos me levaram para jogar Rugby, que é a versão do futebol americano, só que sem proteção e ao invés de passar a bola para frente é para trás e para os lados. Eu treino no time do Benfica aqui de Portugal e vou aos treinos após as aulas ou quando tenho folga.

O que menos gosto aqui em Portugal é dos brasileiros que vem para cá, que em vez de estar a trabalhar estão roubando, e com isso somos prejudicados, isso leva ao racismo, porque aqui falam que brasileiro não presta.

O mais difícil aqui é fazer amizades, boas amizades, porque fazer amizades com quem não presta só leva à discriminação, então eu prefiro escolher bem as minhas amizades e ficar longe de brasileiros.

A problemática da aceitação no grupo fica evidente e apresenta-se complexa porque envolve uma série de elementos que abrangem e constituem aspectos próprios do contexto migratório, percebe-se que o jovem vive uma verdadeira crise de pertencimento, nem um nem outro, nem brasileiro, nem português.

O cenário apresentado é um claro exemplo de processos de negociação da identidade, pois envolve o (re)conhecimento da própria identidade, uma vez que o jovem se atribui certos traços e rejeita outros, utilizando um conjunto de manobras, criadas em relações imaginárias de auto inclusão em relação aos jovens portugueses, que correspondem a mecanismos de defesa para aliviar a ansiedade e o sentimento de inferioridade e, ao mesmo tempo, corresponde a um mecanismo de aproximação ao jovens portugueses. Nesse sentido, a estratégia identitária adotada torna-se um processo interativo de auto consciência e é influenciada pelo olhar do outro, através dos mecanismos de comparação e categorização social, buscando reconhecimento, valorização e, 
principalmente, a aceitação no grupo, alimentando a esperança de que é possível chegar e se identificar ao grupo de referência.

Para Camilleri (2013), a adoção dessa estratégia pode causar conformismo cultural, perda da identidade, mudanças no físico (cabelo, roupas etc.). Levada ao extremo, pode causar uma ruptura com os laços familiares e com a comunidade de pertença. Essas situações identificadas pelo autor estão evidenciadas no depoimento do jovem, que vive uma verdadeira agonia identitária, pois, na condição de imigrante, precisa conviver e aceitar a cultura portuguesa, mesmo com pouca identificação. Em outros trechos do depoimento, revela que no lar prevalece "o coração brasileiro", o arroz com feijão, canais de televisão brasileiros, internet para falar com amigos brasileiros, o sotaque brasileiro. E, para o convívio social e a aceitação no grupo, ora assume a identidade do brasileiro/português e por vezes do português. Mesmo vestido de angústia e sofrimento, tenta assumir diferentes identidades pois, conforme argumenta Bauman (2005), na sociedade líquido moderna, poder re(inventar) a identidade, ter identidade flutuante significa ser bem visto pelo grupo, nesse caso, não no grupo de origem, mas, aquele que no momento lhe serve de referência.

Se a aceitação no grupo depende de negociar a própria identidade, ou seja, perder a identidade brasileira e ceder lugar a uma identidade ainda não construída, a necessidade brusca de uma nova identidade gera angústia, sofrimento e ansiedade. Nesse sentido, Elias; Dunning (1992, p. 68) afirmam: “[...] a contenção de sentimentos fortes, no sentido de alguém preservar um controle regular firme e completo dos impulsos, afetos e emoções é um fator de origem de novas tensões", que podem ser verificadas sob dois ângulos, o primeiro diz respeito à negação da imagem dos brasileiros, e, o segundo, o conflito na (re)invenção da identidade, pela necessidade de precisar esconder a identidade brasileira.

Normalmente os brasileiros orgulham-se de serem brasileiros; mesmo longe da sua terra natal, procuram ostentá-la, seja no uso de uma camisa com as cores do Brasil, seja portando uma bandeira, ou simplesmente falando o português brasileiro; nesse sentido, precisar esconder a sua identidade, negar o convívio com jovens da mesma origem, ter uma identidade flutuante, ora isso, ora aquilo, é fator gerador de constantes tensões e conflitos pessoais, familiares e com outros brasileiros.

Ao se defrontar com um conjunto de representações negativas por meio das quais a sociedade receptora lhe atribui uma identidade simbólica estigmatizada, de forma tão intensa, até mesmo a forma de falar (sotaque) do português brasileiro se converte em elemento discriminador, já que é a mais perceptível e clara marca identitária da sua origem; assim, o jovem busca formas de abandonar o mais breve possível o seu sotaque de origem e aprender corretamente o sotaque 
português, seja por meio das aulas, da televisão e treinando sozinho nas ruas; consequentemente, deseja rapidamente perder o sotaque brasileiro para que possa não ter a identidade de origem revelada, numa tentativa de reconstruir os elementos de diferenciação.

A tensão na (re)invenção da identidade, ou seja, primeiro negar, em seguida esconder a própria identidade cultural, confronta-se com uma realidade que força olhar para os "outros" brasileiros com o mesmo olhar de discriminação e preconceitos lançado pela sociedade portuguesa, ou seja, há não apenas a incorporação dos seus valores e cultura, por ele percebido como os "superiores", mas também atribui aos brasileiros os mesmos estereótipos vistos pelos portugueses. Normalmente "os grupos humanos têm a tendência a desenvolver definições positivas de si mesmos, enquanto, por outro lado, produzem definições negativas do Outro" (FABIETTI, 1998 apud Malizia, 2011, p. 3); contradizendo o autor, esse contexto de tensão na (re)invenção identitária faz com que o jovem sinta necessidade de construir uma imagem negativa do próprio grupo e positiva do grupo no qual pretende inserir-se.

A necessidade de amigos, tão importante nessa idade, e a ausência de identificações criam uma identidade semelhante ao controle da televisão, "esse" e "aquele", agora eu sou "brasileiro", daqui a pouco "português", gerando uma instabilidade de equilíbrio, que nasce e renasce em conflitos, nas memórias e nos projetos. O conflito interior se dá ao buscar referências naquilo que ele "era" com aquilo pensa que "é" e ainda com o que "gostaria ser", gerando sentimentos confusos e conflitantes, assumindo a identidade como recurso que mobiliza para estabelecer demarcações, visando um efeito apenas performativo.

Para esse jovem, a (re)invenção da identidade ocorre num contexto de formação da personalidade, no período entre adolescência e mundo adulto, em que o indivíduo se revela mais frágil emocionalmente.

As radicais mudanças na forma de ser, de sentir, de agir e de viver a juventude forçam esse jovem a uma adaptação muito rápida à identidade portuguesa e, ao mesmo tempo, a uma rejeição da sua identidade cultural de origem. Isto posto, considera-se que ele pode tornar-se um estranho dentro da sua própria cultura, não conseguindo mais se comunicar com os jovens do país de origem. Há, portanto, uma crise de identidade valorizada por Dubar (2006, p. 185) porque "é de facto a crise que revela o sujeito a ele próprio, o obriga a refletir, a mudar, a lutar para 'a superar' e inventar-se a si próprio, com os outros. A identidade pessoal não se constrói de outra forma", no entanto, o jovem oscila entre o sonho e o pesadelo, sonho em ser português, mas o é, pesadelo em ser brasileiro, e o é; ou, ao contrário, pesadelo em aparentar ser português, e sonho em poder assumir a condição de brasileiro. 
A agonia identitária é tão forte que o jovem trava uma verdadeira guerra; de um lado está a identidade desejada que é abominada pelo irmão, por outro, está a identidade que ele abomina e deseja substituir, e que é valorizada pelo irmão, portanto, os conflitos surgem também no lar.

O terceiro tipo de estratégia identitária identificada no corpus da investigação é aqui representada por Paula, 16 anos, negra, natural de Matosinhos, região metropolitana de Belo Horizonte - MG, que vive há seis anos na cidade do Porto com a mãe e o irmão. A mãe migrou sozinha, ela e o irmão permaneceram no Brasil, por um ano, morando com o pai e a madrasta, tão logo a mãe conseguiu dinheiro, enviou-lhes as passagens aéreas. Assim que chegou, Paula começou a frequentar escola, na época da entrevista, além da escola, possuía um contrato de trabalho como modelo em uma agência na cidade do Porto e mostrava-se ansiosa, pois estava de viagem marcada para rever a família no Brasil. A jovem demonstrou adaptação à sociedade portuguesa, mesmo afirmando que se sente brasileira, consegue socializar-se com os jovens portugueses e aos poucos incorporando elementos da cultura juvenil desse país e encontrando formas de conviver e socializar com os jovens portugueses:

Os meus amigos são quase todos portugueses, são todos da escola, conheci todos na escola. [...] Vamos ao café, ao shopping, damos uma volta quando o dia está bom, é sempre assim, vamos ao cinema, costuma ser sempre assim, não se compara com o Brasil.

Eu digo, sou apaixonada por Portugal, se eu tivesse que voltar a morar para o Brasil eu não tinha coragem. A vida que a gente leva no Brasil é completamente diferente da vida que a gente leva aqui, é muito mais fácil aqui que no Brasil, eu acho que sim.

Aqui tem uma lojinha brasileira, e quando dá com aquela vontade matar a saudade a gente vai lá e compra alguma coisa. maria mole, sou doida por maria mole, farinha do Brasil, pimenta, aquelas pimentas no pote, de tudo... E depois quando a minha mãe quer fazer comida brasileira como vaca atolada com mandioca, ela adora mandioca com açúcar, a gente vai comprar assim o que precisa.

Em Matosinhos, lá tem sempre festa brasileira, de segunda até domingo. Todo sábado a gente vai. Embaixo é restaurante e em cima tem um bar, o pessoal vai lá jantar e depois vão lá para cima dançar. Eu gosto muito.

Sou mais brasileira, brasileira sempre, e sinto orgulho de falar que eu sou brasileira, e quando pergunta-me eu respondo: sou brasileira. Gosto do Brasil e gosto de ser brasileira.

Os trechos do depoimento da jovem permitem perceber uma estratégia por distinção (CAMILLERI, 2013), ou seja, a moderação no discurso tanto da sociedade de origem quanto da sociedade de acolhimento e a compreensão de que o processo de construção de identidade encontra-se em constante transformação, na medida em os indivíduos se relacionam, quer com o grupo a que pertence, quer com o "outro" grupo. Não se trata de desconstruir a identidade, mas 
reconstrui-la ou reinventá-la por meio de diferentes marcadores, que encontram na convivência com os jovens portugueses e colocam o desafio da aceitação no grupo.

Percebe-se que nesse caso há uma assimilação natural da nova cultura, a identificação com a forma de ser e pensar dos jovens portugueses ocorre naturalmente, o que certamente facilita a integração, e a construção de um discurso positivo sobre os jovens e sobre a sociedade acolhedora, sem romper com as suas origens. Nesse caso, segundo (CAMILLERI, 2013), ao adotar essa estratégia, o indivíduo tem consciência de suas diferenças, mas não interioriza as identidades negativas lhes são atribuídas; assim, encontra um equilíbrio identitário, dando lugar a um discurso relativamente moderado das duas sociedades.

Não há para os jovens outra saída; ou busca a aceitação do grupo e encontra amigos para "sair" e conversar ou entra num processo de isolamento, muitas vezes gerador de depressão e angústia, como visto nos casos anteriores.

Ao redesenhar as fronteiras identitárias, incluindo elementos das duas culturas, os horizontes se alargam com plasticidade e novos elementos de identidade vitais são incluídos para a (re)construção e a afirmação identitária - e da diferença.

Certamente que a maioria dos jovens sente necessidade de partilha das experiências próprias desta fase da vida; isso tem um peso maior para a conquista de relações de amizades, seja com jovens brasileiros, com portugueses, ou jovens de outras nacionalidades, porque são nesses relacionamentos que ocorrem os processos partilhados de aprendizagem e descobertas do significado da vida social, portanto, o contato entre as duas culturas tende a tornar a relação mais rica de significados.

Desse modo, Paula nunca deixará de ser brasileira e nunca será portuguesa, mas nesse movimento entre as memórias que carrega dos familiares e amigos que ficaram no Brasil e a nova vida, a família e novos amigos no país acolhedor construirá a sua vida, buscando o que é desejo de todos, ser feliz.

\section{APONTAMENTOS FINAIS}

Não a título de conclusão, mas apenas como apontamentos finais acerca da análise desse excerto de uma pesquisa mais ampla, é possível afirmar que em função dos diferentes conflitos identitários, os jovens em contexto migratório são constantemente forçados a negociar as bases de suas interações sociais e, desse modo, optar por uma ou mais estratégias identitárias, dependendo do contexto social e cultural que encontra na sociedade de acolhimento. Portanto, as estratégias

identitárias são destinadas a preservar ou adquirir uma identidade social que lhe permita sobreviver da melhor forma possível. Afirmam Camilleri e seus colegas (2013) que as estratégias 
identitárias que levam os jovens a adaptar-se ao contexto temporal e espacial são múltiplas e mudam de acordo com as variáveis que intervêm e que têm como finalidade evitar ou moderar o conflito interno da pessoa que vive entre duas culturas.

Sendo assim, se, por um lado, os jovens têm as condições materiais (melhores salários, moradias, bens materiais e vestimenta, item importante para o jovem) e, principalmente, de segurança pública que lhe oferece Portugal, por outro, conhecem e carregam memórias do país de origem onde possuem inúmeras amarras afetivas, sociais e culturais que serviram de base na construção de suas identidades.

Desenraizados da sua cultura, longe dos amigos de infância, a ausência de reconhecimento pela sociedade acolhedora, a dificuldade de estabelecer vínculos mais profundos de amizade contribuem para construção de uma identidade dividida, por vezes contraditória e incerta, e recorrer a diferentes estratégias significa colocar a sua identidade em constante conflito.

Por outro lado, é importante ressaltar que, ao considerar a identidade um processo dinâmico que se constrói e reconstrói, como algo sempre em "processo" (Hall, 2000), ou como produto das sucessivas socializações (Dubar, 2006), ou ainda, como adverte Bauman (2005), da necessidade da sociedade líquido moderna de manter diversas identidades, uma ou mais estratégia utilizada realçam a necessidade dos jovens brasileiros que vivem em Portugal manejarem as clivagens interiores e as contradições sociais e culturais nas quais estão imersos, que, na circunstância posta de imigrantes, provocam rupturas e descontinuidades, mas também possibilidade de (re)construção identitária.

Sob influências diversas e porventura conflitantes, os jovens precisam encontrar o caminho para afirmarem sua própria identidade; trata-se muitas vezes de percorrer por uma trilha incerta até obter o reconhecimento dos diferentes grupos sociais do país de acolhimento.

Por fim, é importante ressaltar que ao privilegiar a identidade como foco de análise em estudos migratórios significa reconhecer a sua centralidade e as formas de conhecimentos que os imigrantes produzem acerca de si próprios e da sua cultura, assim como, da sociedade e da cultura do país que escolheram para viver.

\section{REFERÊNCIAS}

BAUMAN, Zygmunt. Identidade: entrevista a Benedetto Vecchi. Rio de Janeiro: Jorge Zahar, 2005.

CAMILLERI, Carmel et al. Stratégies identitaires. Paris: Press Universitaires de France - PUF, 2013.

DUBAR, Claude. A crise das identidades: A interpretação de uma mutação. Porto: Afrontamento, 2006. 
ELIAS, Norbert; DUNNING, Eric. A busca da excitação. Lisboa: Difel, 1992.

HALL, Stuart. A identidade cultural na pós-modernidade. Rio de Janeiro: DP\&A, 2006.

HALL, Stuart. “Quem precisa da identidade?”. IN: Silva, Tomas Tadeu da (Org.), Identidade e diferença. A perspectiva dos estudos culturais. Petrópolis: Vozes, 2000.

KASTERSZTEIN, Joseph. Les stratégies identitaires des acteurs sociaux: approche dynamique des finalités. In CAMILLERI, Carmel et al. Stratégies identitaires. Paris: Press Universitaires de France - PUF, 2013.

LIPIANSKY, Edmond-Marc; TABOADA-LEONETTI, Isabelle, VASQUEZ, Ana. Introduction à la problématique de 1'identité. In: CAMILLERI, Carmel et al. Stratégies identitaires. Paris: Press Universitaires de France - PUF, 2013.

MACHADO, Igor José de Renó, Cárcere Público: Processos de Exotização do Imigrante Brasileiro em Portugal, tese de doutoramento em Ciências Sociais, Universidade Estadual de Campinas, 2003.

MALHEIROS, Jorge. Os brasileiros em Portugal: a síntese do que sabemos. In: MALHEIROS, Jorge Macaísta (Org.) Imigração Brasileira em Portugal. ACIDI, Lisboa, 2007.

MALIZIA, Pierfranco. 0 " $x$ " do problema. Uma pesquisa acerca das representações sociais do Outro-estrangeiro como suporte ao preconceito e à desigualdade na Europa "quasemultiétnica". XI Congresso Luso Afro Brasileiro de Ciências Sociais. Salvador, 07 a 10 de agosto de 2001. Disponível em:

http://www.xiconlab.eventos.dype.com.br/resources/anais/3/1304490483_ARQUIVO_Oxdoprobl ema.pdf . Acesso em: 28 abr 2015.

PADILLA, Beatriz. Integração dos “Imigrantes brasileiros recém-chegados" na sociedade portuguesa: problemas e possibilidades. In: MACHADO, Igor José de Renó. (Org.) Um mar de identidades: $a$ imigração brasileira em Portugal. São Carlos: EDUFSCAR, 2006.

PADILLA, Beatriz. A imigração brasileira em Portugal: considerando o género em análise. In: MALHEIROS, Jorge. (Org.) Imigração Brasileira em Portugal, Lisboa: ACIDI, 2007.

PEIXOTO, João; FIGUEIREDO, Alexandra. Imigrantes brasileiros e mercado de trabalho em Portugal. In: MACHADO, Igor José de Renó. (Org.) Um mar de identidades: $a$ imigração brasileira em Portugal. São Carlos: EDUFSCAR, 2006.

TABOADA-LEONETTI, Isabelle. Stratégies identitaires et minorités: le point de vue du sociologue. In: CAMILLERI, Carmel et al. Stratégies identitaires. Paris: Press Universitaires de France - PUF, 2013. 